\title{
Correction to: Adverse drug reactions in older adults: a narrative review of the literature
}

\author{
Maria Beatrice Zazzara ${ }^{1}$ (D) $\cdot$ Katie Palmer ${ }^{1} \cdot$ Davide Liborio Vetrano $^{1,2} \cdot$ Angelo Carfi $^{1} \cdot$ Graziano Onder $^{3}$
}

Published online: 22 November 2021

(c) The Author(s) 2021

\section{Correction to: \\ European Geriatric Medicine (2021) 12:463-473 \\ https://doi.org/10.1007/s41999-021-00481-9}

In the original version of this article, the given name and family name of Graziano Onder were interchanged. The corrected author list is given above. The original article has been corrected.

Open Access This article is licensed under a Creative Commons Attribution 4.0 International License, which permits use, sharing, adaptation, distribution and reproduction in any medium or format, as long as you give appropriate credit to the original author(s) and the source, provide a link to the Creative Commons licence, and indicate if changes were made. The images or other third party material in this article are included in the article's Creative Commons licence, unless indicated otherwise in a credit line to the material. If material is not included in the article's Creative Commons licence and your intended use is not permitted by statutory regulation or exceeds the permitted use, you will need to obtain permission directly from the copyright holder. To view a copy of this licence, visit http://creativecommons.org/licenses/by/4.0/.

Publisher's Note Springer Nature remains neutral with regard to jurisdictional claims in published maps and institutional affiliations.

The original article can be found online at https://doi.org/10.1007/ s41999-021-00481-9.

Maria Beatrice Zazzara

mbeatricezazzara@outlook.com

1 Department of Gerontology, Fondazione Policlinico Gemelli IRCCS, Rome, Italy

2 Aging Research Center, Department of Neurobiology, Care Sciences and Society, Karolinska Institutet, Stockholm, Sweden

3 Department of Cardiovascular, Endocrine-Metabolic Diseases and Aging, Istituto Superiore di Sanità, Rome, Italy 